\title{
Peran kepemimpinan transformasional dalam meningkatkan employee engagement dan dampaknya pada kinerja pegawai
}

\author{
R. Afiani ${ }^{1}$, A. Surachim \& M. Masharyono \\ Universitas Pendidikan Indonesia \\ riskaafiani@upi.edu
}

\begin{abstract}
The objectives of this research are to determine whether how much influence transformational leadership has on employee engagement and its implications for the performance of employees of public sector organizations. The design of this study was a cross-sectional method and used descriptive and verification type research methods. Data for this study were collected using a saturated sample with a total sample of 40 people. Analysis of this research data using simple linear regression with SPSS 24.0 for Windows computer software program (Statistical Product for Service Solution). The results of this study indicate that transformational leadership in public sector organizations is quite effective, employee engagement is in the high category and employee performance is in the high category. The current study found that the impact of effective transformational leadership can increase employee engagement and vice versa, if transformational leadership is not effective then employee engagement will not increase. This also happens to employee performance, if employee engagement is low it will result in low employee performance and conversely if employee engagement is high then the performance of employees will also increase.
\end{abstract}

Keywords: Employee Engagement; Employee Performance; Transformational Leadership; Public Organization

Abstrak: Penelitian ini dilakukan guna mengetahui seberapa besar pengaruh kepemimpinan transformasional terhadap employee engagement serta implikasinya pada kinerja pegawai organisasi sektor publik. Desain penelitian ini adalah cross sectional method dan menggunakan metode penelitian jenis deskriptif dan verifikatif. Data untuk penelitian ini dikumpulkan menggunakan sampel jenuh dengan jumlah sampel yang diteliti sebanyak 40 orang. Analisis data penelitian ini menggunakan regresi linier sederhana dengan alat bantu software komputer program SPSS (Statistical Product for Service Solution) 24.0 for windows. Berdasarkan hasil penelitian dapat diketahui bahwa kepemimpinan transformasional pada organisasi sektor publik cukup efektif, employee engagement dalam kategori tinggi dan kinerja pegawai berada dalam kategori tinggi. Studi saat ini menemukan bahwa dampak dari efektifnya kepemimpinan transformasional dapat meningkatkan employee engagement begitu pun sebaliknya, apabila kepemimpinan transformasional tidak efektif maka employee engagement tidak akan mengalami peningkatan. Hal tersebut pun terjadi pada kinerja pegawai, apabila employee engagement rendah maka akan menghasilkan kinerja pegawai yang rendah pula dan sebaliknya jika employee engagement tinggi maka kinerja pegawai pun akan mengalami peningkatan.

Kata Kunci: Employee Engagement; Kinerja Pegawai; Kepemimpinan Transformasional; Organisasi Publik 


\section{PENDAHULUAN}

Bagian yang sangat penting dalam organisasi adalah manusia sebagai sumber daya yang dapat menunjang organisasi melalui karya, bakat, kreativitas, dorongan dan peran nyata seperti yang dapat dilihat dalam setiap organisasi (Masharyono \& Senen, 2015:132). Kinerja pegawai merupakan hal yang sangat penting dalam upaya perusahaan atau organisasi untuk mencapai tujuannya (Senen, Sumiyati, \& Masharyono, 2016). Dapat dikatakan bahwa kinerja pegawai sebagai suatu fondasi organsasi dan menjadi salah satu faktor dasar untuk meningkatkan kinerja organisasi itu sendiri, maka dari itu kinerja pegawai merupakan suatu perilaku yang harus diperhatikan karena kinerja yang dihasilkan oleh pegawai sangat berpengaruh bagi organisasi (Obicci, 2015). Hal tersebut menegaskan bahwa apabila kinerja seorang pegawai baik maka kemungkinan besar kinerja organisasi akan baik pula. Kinerja pegawai yang baik didukung oleh kemampuan dan pengetahuan tentang karakteristik pekerjaan sehingga akan membantu pegawai dalam menyelesaikan pekerjaannya (Masharyono \& Senen, 2015:122).

Dalam artian sempit kinerja pegawai dikatakan sebagai produktivitas pegawai sementara dalam arti luas diartikan sebagai kombinasi dari upaya, keterampilan, dan hasil yang diperoleh dan sangat penting bagi pegawai dan organisasi. Kinerja pegawai adalah satu set perilaku dengan unsur-unsur evauatif pegawai yang dapat menjadi positif atau negatif (Nikbin, 2016). Dapat disimpulkan bahwa kinerja pegawai merupakan unjuk kerja pegawai dala melaksanakan keseluruhan dari tugas yang menjadi kewajibannya dalam bekerja. Tugas-tugas tersebut berdasarkan keberhasilan yang sudah ditetapkan, sebagai hasilnya akan diketahui bahwa seorang pegawai digolongkan dalam tingkatan kinerja tertentu (Fattah, 2017:10).

Kinerja pegawai memiliki banyak dimensi, salah satunya diungkapkan oleh Gibson (2012) yang mengemukakan dimensi kinerja pegawai diantaranya adalah, (1) individual characteristics (karakteristik individual). Psikologi dan sosial psikologi individu menyumbangkan pengetahuan yang relevan tentang hubungan antara sikap, persepsi, kepribadian, nilai dan kinerja individu, (2) individual motivation (motivasi individual).
Motivasi dan kemampuan untuk berinteraksi saat bekerja menenetukan kinerja pegawai. Teori motivasi mencoba untuk menjelaskan dan memprediksi bagaimana cara membangkitkan, melanjutkan dan memberhentikan perilaku individu, dan (3) rewards and appraisal (penghargaan dan penilaian). Salah satu pengaruh yang kuat dalam kinerja pegawai adalah sistem rewards (penghargaan) dari perusahaan. Manajemen dapat menggunakan penghargaan untuk meningkatkan kinerja pegawai saat ini.

Permasalahan kinerja pegawai telah banyak diteliti oleh sejumlah peneliti di dunia dari berbagai sektor, seperti sektor manufaktur, perbankan, pendidikan, organisasi publik, dan sebagainya (Iqbal, Rehan, Fatima, \& Nawab, 2017). Kinerja pegawai dalam sektor oganisasi publik mendapat perhatian yang relatif rendah dibandingkan dengan sektor lain, seperti sektor swasta, maka masih diperlukan banyak penelitian dalam sektor ini (Iqbal et al., 2017). Salah satu penelitian mengenai kinerja pegawai di sektor organisasi publik diteliti di Pakistan, penelitian tersebut mengungkapkan bahwa organisasi masih perlu mengembangkan lingkungan dan sumber daya yang ada kepada pegawai guna mendapatkan kinerja pegawai yang lebih baik (Iqbal et al., 2017). Rendahya kualitas dan kelambanan pelayanan merupakan hal yang lazim terjadi dalam kinerja organisasi pelayan publik di Indonesia. Hal tersebut sampai sekarang masih banyak dikeluhkan oleh pengguna layanan publik dan mendapat sorotan untuk diadakan pembenahan (Pidesia, Karim, \& Irawan, 2016:73). Penelitian mengenai kinerja pegawai dalam organisasi publik di Indonesia salah satunya diteliti di Disparbud Jabar. Hasil dari penelitian tersebut mengemukakan bahwa kinerja yang dimiliki oleh pegawai dalam organisasi tersebut masih kurang baik, hal tersebut tercermin dari kurang semangatnya pegawai datang ke tempat kerja (Masharyono, 2015:814).

Masalah mengenai kinerja pegawai pun terjadi di salah satu organisasi sektor publik. Hal tersebut yang mendorong peneliti untuk melakukan penelitian pada organisasi sektor publik tersebut. Berdasarkan hasil pra penelitian pada pegawai organisasi sektor publik tersebut menunjukkan kinerja pegawai yang relatif rendah dengan jumlah skor rata-rata sebesar $63,33 \%$ dari target yang telah ditetapkan oleh pemerintah yaitu sebesar $100 \%$. Kinerja pegawai yang rendah dapat disebabkan 
oleh banyak faktor, salah satunya adalah employee engagement. Beberapa studi membuktikan bahwa employee engagement dapat berdampak baik atau buruk pada kinerja pegawai, hal ini menunjukkan bahwa employee engagement merupakan faktor penentu utama dalam mendorong tingkat kinerja pegawai (Anitha, 2013). Pegawai yang terlibat dalam pekerjaannya memiliki motivasi yang tinggi dalam bekerja dan senantiasa mempromosikan tujuan organisasi (Kiersch, 2014). Motivasi tersebut dapat diperlihatkan dengan kinerja dan semangat pegawai dalam bekerja (Frank, Finnegan, \& Taylor, 2004).

Employee engagement yaitu keterlibatan seorang individu, kepuasan, dan antusiasme tehadap pekerjaan yang dilakukan. Pekerja yang sangat terlibat memiliki gairah dalam pekerjaannya dan merasakan hubungan yang dalam dengan perusahaannya, pekerja yang tidak terlibat telah keluar secara esensial-menghabiskan waktu tetapi bukan energi atau perhatian pada pekerjaannya. Keterlibatan menjadi sebuah fokus utama untuk kebanyakan organisasi karena kebanyakan survei mengindikasikan bahwa sedikit pekerja antara $17 \%$ dan $29 \%$ yang memiliki keterlibatan tinggi terhadap pekerjannya (Robbins \& Judge, 2015).

Employee engagement memiliki banyak dimensi, salah satunya diungkapkan oleh Schaufeli (2002) yang mengemukakan dimensi kinerja pegawai diantaranya adalah, (1) vigor (semangat), adalah sesuatu dalam diri seseorang yang terus menerus memberikan semangat, fokus dan energi yang diperlukan untuk sukses. Semangat dicirikan sebagai energi tingkat tinggi dan ketahanan mental saat bekerja, serta kemampuan untuk menginvestasikan upaya dalam pekerjaan dan ketekunan bahkan dalam menghadapi kesulitan (Kaswan, 2015:166). Mereka pun memiliki harga diri yang tinggi yang ditunjukkan oleh kepercayaan diri dalam keterampilan, kemampuan dan hubungan sosial (Widjajanta, Senen, Masharyono, Lisnawati, \& Anggraeni, 2018), (2) dedication (Dedikasi), ditenggarai oleh perasaan bermakna, semangat, inspirasi, bangga, dan tantangan di tempat kerja. Dedikasi merujuk kepada hal yang sangat terlibat dalam pekerjaan terkait dengan pengalaman pekerjaan yang bermakna, dan merupakan tanda bahwa seseorang bangga atas pekerjaannya, dan (3) absorption (penyerapan), menunjukkan bahwa orang begitu berkonsentrasi, bahagia, dan menyerap pekerjannya sehingga waktu berlalu begitu cepat dan karyawan sulit memisahkan dirinya dari pekerjaan. Penyerapan ditandai dengan meningkatnya konsentrasi, senang ketika melakukan pekerjaan, dan merasa sulit melepaskan diri dari pekerjaan (Kaswan, 2015:166).

$$
\text { Employee engagement menjadi }
$$

permasalahan yang mendapat perhatian selama satu dekade (10 tahun terakhir sejak tahun 1996an) karena memiliki dampat bagi perekonomian (Mann \& Harter, 2016). Para pemimpin organisasi mengakui bahwa employee engagement sebagai elemen penting yang mempengaruhi efektivitas, inovasi dan daya saing organisasi (Welch, 2009). Adanya permasalahan tersebut konstruk employee engagement menarik minat yang kuat dan menerima banyak perhatian dalam lima tahun terakhir di kalangan konsultan sumber daya manusia, praktisi komunikasi internal, dan konferensi bisnis (Council, 2016).

AON Hewitt melakukan penelitian terhadap employee engagement pada tahun 2016 dan mendapatkan hasil bahwa employee engagement mengalami penurunan yang disebabkan oleh kemajuan teknologi yang lebih canggih sehingga penggunaan tenaga kerja, pengalaman kerja, dan keterlibatan pegawai menjadi menurun (Hewitt, 2017). Employee engagement di Indonesia menunjukkan hasil bahwa karyawan belum mencapai engaged yang tinggi. Hal ini diperkuat oleh sebuah studi bertajuk "Employee Engagement Among Millennials" (2016), yang dilakukan oleh Dale Carnegie Indonesia (DCI) menyebutkan hanya 20\% tenaga kerja di Indonesia mulai dari kelahiran tahun 19862000 yang terlibat sepenuhnya (full engaged) dengan perusahaan tempat mereka bekerja (Youngster.id, 2017). Employee engagement pun menjadi salah satu masalah yang terjadi pada organisasi sektor publik. Berdasakan hasil pra penelitian pada pegawai organisasi sektor publik menunjukkan employee engagement yang relatif rendah dengan jumlah skor rata-rata sebesar $72,73 \%$ dari target $100 \%$.

Kebebasan pegawai untuk terlibat dalam pekerjaan tergantung pada kepemimpinan dan manajemen organisasi. Intervensi yang dilakukan oleh pemimpin dipercaya dapat membina bawahan agar lebih terlibat dalam pekerjaanya. Intervensi pemimpin harus mempertimbangkan kapasitas, motivasi dan kebebasan bawahan untuk terlibat 
(Macey, W.H., Schneider, B., Barbera, K.M. and Young, 2011). Uraian di atas dapat menjadi salah satu upaya yang harus dilakukan oleh organisasi sektor publik untuk meningkatkan employee engagement yakni dengan meningkatkan kualitas pemimpin menjadi pemimpin transformasional. Kepemimpinan transformasional adalah salah satu tipe kepemimpinan yang tepat untuk meningkatkan keterlibatan pegawai dalam mengerjakan pekerjannya (Shuck \& Herd, 2012). Pemimpin yang memiliki kepemimpinan transformasional menunjukkan sikap semangat dan antusiasme, hal tersebut merupakan bagian inti dari keterlibatan (Macey, W.H., Schneider, B., Barbera, K.M. and Young, 2011). Peran kepemimpinan sangat penting bagi suatu organisasi atau organisasi karena seorang pemimpin merupakan pemegang kendali dan pengambil keputusan organisasi. Tanpa adanya peran kepemimpinan maka tujuan organisasi tidak akan berjalan sesuai dengan rencana awal dan akan berimbas pada kinerja organisasi itu sendiri (Shuck \& Herd, 2012).

Kepemimpinan transformasional memiliki banyak dimensi, salah satunya diungkapkan oleh Bass (1985) yang mengemukakan dimensi kinerja pegawai diantaranya adalah, (1) idealized influence (pengaruh ideal atau karisma), yaitu sebagai pemimpin harus dapat menjadi figur yang diidealkan, ia mampu menyampaikan keyakinan atas nilai-nilai luhur yang menjadi pegangan, menekankan pentingnya suatu tujuan, komitmen, dan konsekuensi etis dari suatu keputusan, (2) individualized consideration (kepekaan individual), yaitu pemimpin harus dapat berhubungan dengan pengikutnya sebagai makhluk pribadi yang memiliki kebutuhan, kemampuan dan keinginan, mendengarkan dengan penuh perhatian, mengembangkan potensi pengikutnya, menasehati dan membimbing pengikutnya, (3) inspirational motivation (motivasi inspirasional), yaitu pemimpin yang dapat mengartikulasi visi dan misi masa depan organisasi, menantang pengikutnya dengan standar yang tinggi, berbicara secara optimis dan penuh antusiasme, memberikan dorongan untuk bekerja lebih giat, dan (4) intellectual stimulation (stimulasi intelektual), yaitu pemimpin harus dapat menstimulasi hadirnya perspektif dan cara baru dalam menyelesaikan suatu pekerjaan serta mendorong pengikutnya untuk menyampaikan ideide dan gagasan-gagasan baru.
Rumusan masalah pada penelitian ini adalah : (1) bagaimana efektivitas kepemimpinan transformasional pada organisasi sektor publik, (2) bagaimana tingkat employee engagement pada organisasi sektor publik, (3) bagaimana tingkat kinerja pegawai pada organisasi sektor publik, (4) apakah terdapat pengaruh kepemimpinan transformasional terhadap employee engagement pada organisasi sektor publik, dan (5) apakah terdapat pengaruh employee engagement terhadap kinerja pegawai organisasi sektor publik.

Adapun tujuan dari penelitan ini adalah (1) untuk memperoleh gambaran kepemimpinan transformasional pada organisasi sektor publik, (2) untuk memperoleh gambaran employee engagement pada organisasi sektor publik, (3) untuk memperoleh gambaran kinerja pegawai pada organisasi sektor publik, (4) untuk memperoleh temuan pengaruh kepemimpinan transformasional terhadap employee engagement pada pegawai organisasi sektor publik, dan (5) untuk memperoleh temuan pengaruh employee engagement terhadap kinerja pegawai pada organisasi sektor publik.

\section{METODE PENELITIAN}

Penelitian ini dilakukan untuk mengetahui pengaruh kepemimpinan transformasional terhadap employee engagement serta implikasinya pada kinerja pegawai. Variabel bebas (independent variable) yang terdapat pada penelitian ini yaitu kepemimpinan transformasional dengan dimensi idealized influence (pengaruh ideal atau karisma), individualized consideration (kepekaan individual), inspiration leadership (motivasi inspirasional), dan intellectual stimulation (stimulasi intelektual). Variabel terikat pertama (dependent variable) pada penelitian ini yaitu employee engagement dengan dimensi vigor (semangat), dedication (dedikasi), dan absorption (penyerapan), sedangkan variabel terikat kedua pada penelitian ini yaitu kinerja pegawai yang mencakup dimensi individual characteristic (karakteristik individual), individual motivation (motivasi individu), dan rewards and appraisal (penghargaan dan penilaian). Objek penelitian ini dilakukan di salah satu organisasi sektor publik dan dilakukan pada kurun waktu kurang dari satu tahun yakni mulai dari bulan Mei hingga Agustus 2018.

Penelitian ini dilakukan pada organisasi 
sektor publik terhadap 40 pegawai. Metode penelitian yang digunakan yaitu cross sectional method dengan jenis penelitian deskriptif dan verifikatif. Berdasarkan jenis penelitian tersebut, maka metode yang digunakan dalam penelitian ini adalah explanatory survey yang bertujuan untuk menguji hipotesis antara variabel satu dengan variabel lain. Teknik pengumpulan data yang digunakan adalah studi kepustakaan, studi literatur dan kuesioner (angket). Teknik analisis data yang digunakan yaitu regresi linier sederhana untuk mengetahui hubungan fungsional ataupun kausal antara satu variabel independen dengan variabel dependen. Untuk menguji signifikansi dilakukan uji t dengan alat bantu software komputer program SPSS (Statistical Product for Service Solution) 24.0 for windows.

Secara statistik, hipotesis yang akan diuji dalam rangka pengambilan keputusan penerimaan atau penolakan hipotesis dapat dirumuskan sebagai berikut: (1) Hipotesis $1, \mathrm{H}_{\mathrm{o}}: \rho \leq 0$, artinya tidak terdapat pengaruh dari kepemimpinan transformasional terhadap employee engagement, $\mathrm{H}_{\mathrm{a}}: \rho>0$, artinya terdapat pengaruh dari kepemimpinan transformasional terhadap employee engagement, (2) Hipotesis $2, \mathrm{H}_{\mathrm{o}}: \rho \leq 0$, artinya tidak terdapat pengaruh dari employee engagement terhadap kinerja pegawai, $\mathrm{H}_{\mathrm{a}}: \rho>0$, artinya terdapat pengaruh dari employee engagement terhadap kinerja pegawai, dan (3) Hipotesis $3, \mathrm{H}_{\mathrm{o}}: \rho \leq 0$, artinya tidak terdapat pengaruh dari kepemimpinan transformasional terhadap employee engagement serta implikasinya pada kinerja pegawai, $\mathrm{H}_{\mathrm{a}}: \rho>0$, artinya terdapat pengaruh dari kepemimpinan transformasional terhadap employee engagement serta implikasinya pada kinerja pegawai.

\section{HASIL DAN PEMBAHASAN}

Teknik analisis data verifikatif yang digunakan untuk melihat pengaruh kepemimpinan transformasional $(\mathrm{x})$ terhadap employee engagement (y) serta implikasinya pada kinerja pegawai (z), penelitian ini menggunakan teknik analisis regresi linier sederhana. Berikut ini adalah pengujian hipotesis pengaruh kepemimpinan transformasional terhadap employee engagement. Sebelum melakukan evaluasi terhadap model pengukuran dalam regresi linier sederhana mengenai pengaruh kepemimpinan transformasional terhadap employee engagement maka perlu dilakukan uji asumsi klasik yang dilakukan dalam penelitian ini. Langkah pertama yang dilakukan adalah uji normalitas, hal tersebut dilakukan untuk melihat apakah data hasil penelitian distribusi normal atau tidak. Uji normalitas pada penelitian ini menggunakan rumus kolmogrov-smirnov $z$ test dengan bantuan SPSS 24.0 for windows. Output uji normalitas pada penelitian ini dapat dilihat sebagai berikut.

\section{Tabel 1. Hasil Uji Normalitas}

Kepemimpinan Transformasional Terhadap Employee Engagement

\begin{tabular}{llr}
\hline \multicolumn{3}{c}{ Employee Engagement } \\
\hline \multicolumn{3}{c}{ One-Sample Kolmogorov-Smirnov Test } \\
\hline $\mathrm{N}$ & \multicolumn{2}{c}{$\begin{array}{c}\text { Unstandardized } \\
\text { Residual }\end{array}$} \\
\hline Normal Parameters ${ }^{\mathrm{a}, \mathrm{b}}$ & Mean & .0000000 \\
& Std. & 5.30325220 \\
& Deviation & .121 \\
Most Extreme & Absolute & .121 \\
Differences & Positive & -.091 \\
& Negative & .121 \\
Test Statistic & & $.141^{\mathrm{c}}$ \\
Asymp. Sig. (2-tailed) & & \\
\hline a. Test distribution is Normal. & \\
b. Calculated from data. & \\
c. Lilliefors Significance Correction. & \\
\hline Sumber: Hasil Pengolahan Data, 2018
\end{tabular}

Sumber: Hasil Pengolahan Data, 2018

Hasil uji normalitas dengan KolmogrovSmirnov Z Test diperoleh nilai KSZ, sebesar 0,121 Asymp.Sig. sebesar 0,141 atau > 0,05 maka dapat disimpulkan data tersebut berdistribusi normal. Uji normalitas tersebut diperkuat dengan membuat grafik p-plot untuk memperjelas bahwa data tersebut benar-benar berdistribusi normal.

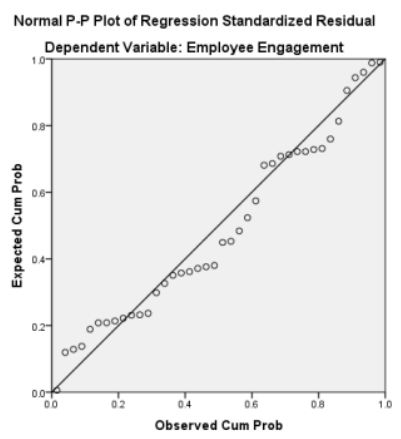

Sumber: Hasil Pengolahan Data, 2018

Gambar 1. Output Uji Normalitas Kepemimpinan Transformasional Terhadap Employee Engagement

Setelah mengetahui bahwa variabel kepemimpinan transformasional dan employee engagement berdistribusi normal, maka 
selanjutnya perlu diketahui apakah kedua variabel tersebut benar-benar memiliki hubungan linear, untuk itu perlu dilakukan uji linearitas regresi variabel kepemimpinan transformasional atas variabel employee engagement. Hasil analisis data linearitas tersebut dapat dilihat pada Tabel di bawah ini.

Tabel 2. Hasil Uji Linearitas Kepemimpinan Transformasional Terhadap Employee Engagement

\begin{tabular}{|c|c|c|c|c|c|c|c|}
\hline \multicolumn{8}{|c|}{ ANOVA Table } \\
\hline & & & $\begin{array}{l}\text { Sum of } \\
\text { Squares }\end{array}$ & Df & $\begin{array}{l}\text { Mean } \\
\text { Square }\end{array}$ & $\mathrm{F}$ & Sig. \\
\hline \multirow{5}{*}{$\begin{array}{l}\text { Employee } \\
\text { Engagement * } \\
\text { Kepemimpinan } \\
\text { Transformasional }\end{array}$} & Between & (Combined) & 1507.233 & 29 & 51.974 & 2.215 & .093 \\
\hline & Groups & Linearity & 645.045 & 1 & 645.045 & 27.488 & .000 \\
\hline & & $\begin{array}{l}\text { Deviation } \\
\text { from } \\
\text { Linearity }\end{array}$ & 862.188 & 28 & 30.792 & 1.312 & .337 \\
\hline & Within G & roups & 234.667 & 10 & 23.467 & & \\
\hline & Total & & 1741.900 & 39 & & & \\
\hline
\end{tabular}

Sumber: Hasil Pengolahan Data, 2018

Hasil pengujian menggunakan uji $\mathrm{F}_{\text {test }}$ didapatkan $F_{\text {hitung }}$ sebesar 1,312 dengan tingkat signifikansi $0,000 \leq 0,05$ artinya variabel kepemimpinan transformasional (X) secara keseluruhan model tersebut sudah fit dan terdapat hubungan antara variabel kepemimpinan transformasional terhadap employee engagement sehingga regresi bisa dipakai untuk memprediksi kinerja pegawai.

Langkah selanjutnya setelah melakukan uji linearitas adalah dengan menguji diagram pencar atau diagram serak (scatter plot) yang digunakan untuk mengetahui dan menunjukkan ada tidaknya hubungan antara variabel kepemimpinan transformasional (x) dan employee engagement (y) melalui penggambaran nilai variabel-variabel tersebut. Hasil pengolahan data tersebut disajikan sebagai berikut.

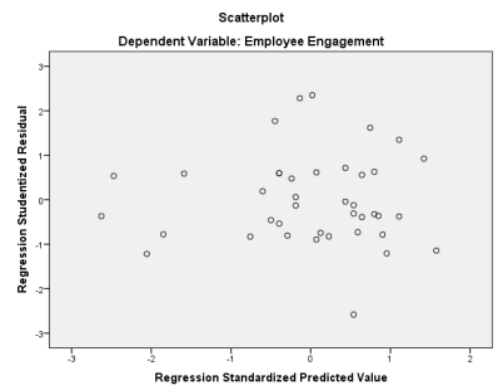

Sumber: Hasil Pengolahan Data, 2018

Gambar 2. Diagram Pencar Kepemimpinan Transformasional Terhadap Employee Engagement
Diagram pencar di atas menggambarkan bahwa titik-titik pada diagram pencar tersebut menyebar dan membentuk pola dari kiri bawah menuju kanan atas. Garis tersebut dapat diketahui kovaransi antara kepemimpinan transformasional (x) dan employee engagement (y) sifatnya searah, dalam arti bahwa apabila kepemimpinan transformasional berubah semakin besar, maka employee engagement pun berubah semakin besar. Setelah diketahui model diagram pencar dan telah menunjukkan pola garis lurus atau linear, langkah selanjutnya adalah memperhatikan titik-titik yang letaknya terpencil pada diagram pencar. Adapun output gambar uji titik terpencil kepemimpinan transformasional terhadap employee engagement dapat dilihat sebagai berikut.

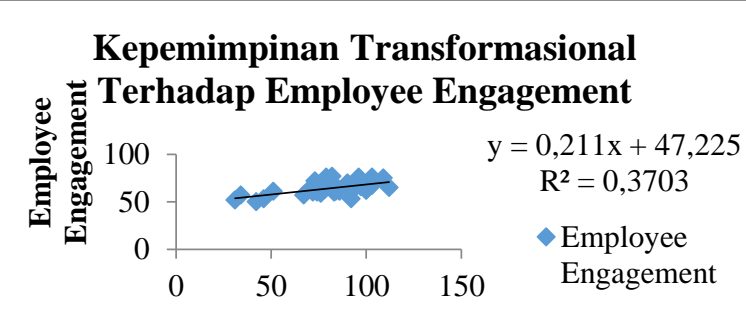

Kepemimpinan Transformasional

Sumber: Hasil Pengolahan Data, 2018

Gambar 3. Output Uji Titik Terpencil

Kepemimpinan Transformasional Terhadap

Employee Engagement

Berdasarkan gambar tersebut, terdapat satu titik hitam yang dicurigai sebagai titik terpencil. Selajutnya untuk mengetahui apakah titik hitam tersebut benar merupakan titik terpencil, maka dilakukan perhitungan dengan menggunakan rumus uji statistik sebagai berikut.

Tabel 3. Hasil Pengujian Titik

Terpencil Kepemimpinan Transformasional

Terhadap Employee Engagement

\begin{tabular}{|c|c|c|c|c|c|c|}
\hline$\hat{\mathbf{Y}}$ & $\mathbf{X}$ & $\mathbf{Y}=\mathbf{a}+\mathbf{b X X}$ & $\begin{array}{c}S_{Y-\hat{Y}} \\
(0,05- \\
\hat{\mathbf{Y}})\end{array}$ & $\begin{array}{c}t_{\text {hitung }} \\
t=\frac{(}{\left.\frac{Y-\hat{Y}}{S_{Y-\hat{Y}}}\right)}\end{array}$ & $\begin{array}{c}t_{\text {tabel }} \\
(40- \\
2)\end{array}$ & Keterangan \\
\hline 61 & 84 & $\begin{array}{l}\mathrm{Y}=0,211 \mathrm{x}+ \\
47,225 \\
\mathrm{Y}= \\
\quad 0,211(84) \\
\quad+47,225 \\
=64,949\end{array}$ & $\begin{array}{l}0,05- \\
61=- \\
60,95\end{array}$ & $\begin{array}{l}\mathrm{t}=3,949 /- \\
60,95 \\
=-0,065\end{array}$ & 1,686 & $\begin{array}{c}\text { Bukan titik } \\
\text { terpencil }\end{array}$ \\
\hline
\end{tabular}

Sumber: Hasil Pengolahan Data, 2018

Hasil pengujian titik terpencil tersebut, dapat diketahui bahwa titik tersebut bukan titik terpencil, karena $t_{\text {hitung }}$ menunjukkan nilai yang lebih kecil daripada $t_{\text {tabel }}(-0,065<1,686)$ sehingga 
kriteria yang digunakan atas hasil perhitungan tersebut adalah diterima $\mathrm{H}_{0}$ yang artinya titik yang mencurigakan tidak dianggap sebagai titik terpencil dan tidak perlu dikeluarkan.

Untuk mengetahui bagaimana pengaruh kepemimpinan transformasional terhadap employee engagement penulis menggunakan analisis regresi linear sederhana guna mengetahui perubahan pengaruh yang terjadi terhadap kedua nilai variabel tersebut. Hasil koefisien regresi dipaparkan sebagai berikut.

Tabel 4. Model Regresi Linear Sederhana Kepemimpinan Transformasional Terhadap Employee Engagement

\begin{tabular}{|c|c|c|c|c|c|}
\hline \multirow[b]{3}{*}{ Model } & Co & ficients & & \multirow[b]{3}{*}{$\mathrm{T}$} & \multirow[b]{3}{*}{ Sig. } \\
\hline & \multicolumn{2}{|c|}{$\begin{array}{c}\text { Unstandardized } \\
\text { Coefficients }\end{array}$} & $\begin{array}{c}\text { Standardized } \\
\text { Coefficients }\end{array}$ & & \\
\hline & \multicolumn{3}{|c|}{ Std. } & & \\
\hline $\begin{array}{ll}1 & \text { (Constant) }\end{array}$ & 47.225 & 3.741 & & 12.622 & .000 \\
\hline Kepemimpinan & .211 & .045 & .609 & 4.727 & .000 \\
\hline Transformasional & & & & & \\
\hline a. Dependent Variabl & Employ & Enga & ment & & \\
\hline
\end{tabular}

Sumber: Hasil Pengolahan Data, 2018

Berdasarkan nilai-nilai di atas maka dapat ditentukan model regresi linear sederhana yang dinyatakan dalam bentuk persamaan sebagai berikut.

$$
\begin{gathered}
\mathrm{Y}=\mathrm{a}+\mathbf{b X} \\
\mathrm{Y}=\mathbf{4 7 , 2 2 5}+\mathbf{0 , 2 1 1} \mathrm{X}
\end{gathered}
$$

Nilai konstanta sebesar 47,225 menyatakan bahwa jika tidak ada kepepimpinan transformasional, maka besarnya employee engagement adalah 47,225. Koefisien regresi pada variabel kepemimpinan transformasional adalah 0,211 yang memiliki arti bahwa setiap terjadi penambahan nilai pada kepemimpinan transformasional akan terjadi peningkatan employee engagement sebesar 0,211. Sebaliknya, jika terjadi penurunan kepemimpinan transformasional, maka akan menurunkan employee engagement sebesar 0,211 satu satuan nilai. Dapat dikatakan bahwa kepemimpinan transformasional yang diterapkan oleh pimpinan akan berpengaruh terhadap tingkat employee engagement. Jika kepemimpinan transformasional kurang efektif, maka employee engagement akan rendah. Berdasarkan nilai signifikansi dari tabel Coefficients diperoleh nilai sebesar 0,000 $<0,05$. Sehingga dapat disimpulkan bahwa variabel kepemimpinan transformasional $(\mathrm{x})$ berpengaruh terhadap variabel employee engagement $(\mathrm{y})$.
Langkah selanjutnya adalah dengan menganalisis koefisien determinasi yang digunakan untuk mengetahui presentase pengaruh dari variabel kepemimpinan transformasional (x) terhadap employee engagement (y). Sehingga nilai $\mathrm{r}$ adalah sebagai berikut.

Tabel 5. Koefisien Determinasi Kepemimpinan Transformasional Terhadap

\begin{tabular}{|c|c|c|c|c|}
\hline \multicolumn{5}{|c|}{ Model Summary $^{\mathbf{b}}$} \\
\hline & & $\mathrm{R}$ & Adjusted R & Std. Error of the \\
\hline Model & $\mathrm{R}$ & Square & Square & Estimate \\
\hline 1 & $.609^{a}$ & .370 & .354 & 5.373 \\
\hline $\begin{array}{l}\text { a. Predi } \\
\text { b. Depe }\end{array}$ & $\begin{array}{l}\text { ctors: } \\
\text { ndent }\end{array}$ & $\begin{array}{l}\text { Constant), } \\
\text { ariable: E }\end{array}$ & $\begin{array}{l}\text { pemimpinan T } \\
\text { loyee Engagen }\end{array}$ & ormasional \\
\hline
\end{tabular}
Employee Engagement

Sumber: Hasil Pengolahan Data, 2018

Berikut adalah hasil perhitungan koefisien determinasi dari kepemimpinan transformasional (x) terhadap employee engagement (y) dengan menggunakan rumus sebagai berikut.

$$
\begin{aligned}
& \mathrm{KD}=\mathrm{r}^{2} \times 100 \% \\
& \text { (Riduwan, 2013:136) }
\end{aligned}
$$

$$
\begin{aligned}
\mathrm{KD} & =\mathrm{r}^{2} \times 100 \% \\
& =(0,609)^{2} \times 100 \% \\
& =0,371 \times 100 \% \\
& =37,1 \%
\end{aligned}
$$

Hasil perhitungan koefisien determinasi untuk kepemimpinan transformasional (x) terhadap employee engagement (y) adalah 37,1\%, dengan kata lain employee engagement dipengaruhi sebesar $37,1 \%$ oleh kepemimpinan transformasional sedangkan 62,9\% dipengaruhi oleh faktor-faktor yang tidak diteliti dalam penelitian ini, misalnya lingkungan kerja, hubungan tim dan rekan kerja, pelatihan dan pengembangan karir, kompensasi, kebijakan organisasi, dan kesejateraan kerja (Anitha, 2013:317). Berikut ini rekapitulasi kepemimpinan transformasional terhadap employee engagement.

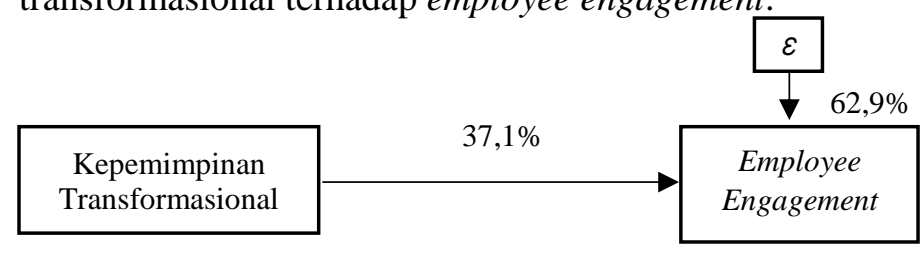

Sumber: Hasil Pengolahan Data, 2018

\section{Gambar 4. Pengaruh Kepemimpinan \\ Transformasional Terhadap Employee Engagement}

Hasil penelitian di atas menunjukkan bahwa terdapat pengaruh antara kepemimpinan 
transformasional terhadap employee engagement, hal tersebut diperkuat oleh penelitian lain yang menyatakan bahwa kepemimpinan transformasional memiliki pengaruh terhadap employee engagement. Salah satu penelitian di perusahaan IT India mengemukakan bahwa kepemimpinan transformasional memiliki pengaruh sebesar $41,8 \%$ terhadap employee engagement dan sisanya dipengaruhi oleh variablevariabel yang tidak diteliti oleh penelitian tersebut (Sangeeta, Avinash, \& Anupam, 2017).

Selanjutnya dilakukan analisis regresi linier sederhana terhadap variabel kepemimpinan transformasional terhadap employee engagement maka langkah selanjutnya dilakukan pengujian hipotesis secara parsial (uji t) terhadap kedua variabel tersebut. Uji statistik $\mathrm{t}$ pada dasarnya menunjukkan seberapa jauh pengaruh satu variabel penjelas/independen secara individual dalam menerangkan variabel dependen (Ghozali, 2011:98). Untuk mengetahui besarnya presentase pengaruh kepemimpinan transformasional terhadap employee engagement, maka diperoleh output sebagai berikut.

Tabel 6. Nilai Signifikansi Uji t

Kepemimpinan Transformasional Terhadap

Employee Engagement

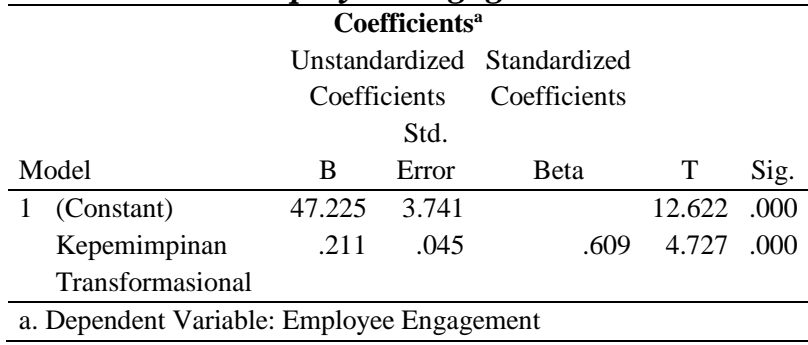

Sumber: Hasil Pengolahan Data, 2018

Diketahui nilai $t_{\text {hitung }}$ sebesar 4,727 $>t_{\text {tabel }}$ sebesar 1,686 dan tingkat signifikansi $(\alpha)$ sebesar $5 \%$ dengan derajat kebebasan $(40-2=38)$, sehingga dapat disimpulkan bahwa $\mathrm{H}_{\mathrm{o}}$ ditolak dan $\mathrm{H}_{\mathrm{a}}$ diterima yang artinya terdapat pengaruh positif antara kepemimpinan transformasional $(x)$ terhadap employee engagement (y) pada organisasi sektor publik.

Setelah melakukan analisis terhadap model pengukuran dalam regresi linier sederhana mengenai variabel kepemimpinan transformasional $(\mathrm{x})$ terhadap variabel employee engagement (y) maka selanjutnya dilakukan analisis terhadap variabel employee engagement (y) terhadap variabel kinerja pegawai (z). Sebelum melakukan evaluasi terhadap model pengukuran dalam regresi linier sederhana mengenai pengaruh employee engagement terhadap kinerja pegawai, maka perlu dilakukan uji asumsi klasik yang dilakukan dalam penelitian ini. Langkah pertama yang dilakukan adalah uji normalitas, hal tersebut dilakukan untuk melihat apakah data hasil penelitian distribusi normal atau tidak. Uji normalitas pada penelitian ini menggunakan rumus kolmogrov-smirnov $z$ test dengan bantuan SPSS 24.0 for windows. Output uji normalitas pada penelitian ini dapat dilihat sebagai berikut.

Tabel 7. Hasil Uji Normalitas Employee

Engagement Terhadap Kinerja Pegawai One-Sample Kolmogorov-Smirnov Test

\begin{tabular}{llr}
\hline \multicolumn{3}{c}{ One-Sample Kolmogorov-Smirnov Test } \\
\hline & & \multicolumn{1}{c}{ Unstandardized } \\
& Residual \\
\hline $\mathrm{N}$ & Mean & .0000000 \\
\cline { 2 - 3 } & Std. & 7.38795024 \\
& Deviation & .142 \\
& Absolute & .087 \\
Most Extreme & Positive & -.142 \\
Differences & Negative & .142 \\
& & $.041^{\mathrm{c}}$ \\
Test Statistic & & \\
Asymp. Sig. (2-tailed) & & \\
\hline a. Test distribution is Normal. & \\
b. Calculated from data. & \\
c. Lilliefors Significance Correction. & \\
\hline Silmber.
\end{tabular}

Sumber: Hasil Pengolahan Data, 2018

Hasil uji normalitas dengan KolmogrovSmirnov Z Test diperoleh nilai KSZ, sebesar 0,142 Asymp.Sig. sebesar 0,141 atau > 0,05 maka dapat disimpulkan data tersebut berdistribusi normal. Uji normalitas tersebut diperkuat dengan membuat grafik p-plot untuk memperjelas bahwa data tersebut benar-benar berdistribusi normal.

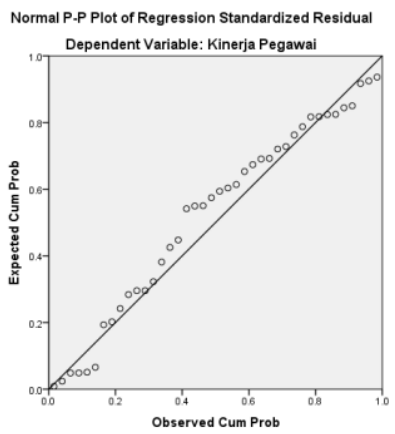

Sumber: Hasil Pengolahan Data, 2018

Gambar 5. Output Uji Normalitas Employee Engagement Terhadap Kinerja Pegawai Setelah mengetahui bahwa variabel employee engagement dan kinerja pegawai berdistribusi normal, maka selanjutnya perlu 
diketahui apakah kedua variabel tersebut benarbenar memiliki hubungan linear, untuk itu perlu dilakukan uji linearitas regresi variabel employee engagement atas variabel kinerja pegawai. Hasil analisis data linearitas tersebut dapat dilihat pada Tabel di bawah ini.

Tabel 8. Hasil Uji Linearitas Employee Engagement Terhadap Kinerja Pegawai

\begin{tabular}{|c|c|c|c|c|c|c|c|}
\hline \multicolumn{8}{|c|}{ ANOVA Table } \\
\hline & & & $\begin{array}{l}\text { Sum of } \\
\text { Squares }\end{array}$ & df & $\begin{array}{c}\text { Mean } \\
\text { Square }\end{array}$ & $\mathrm{F}$ & Sig. \\
\hline \multirow{7}{*}{$\begin{array}{l}\text { Kinerja } \\
\text { Pegawai * } \\
\text { Employee } \\
\text { Engagement }\end{array}$} & Between & (Combined) & 3634.208 & 19 & 191.274 & 3.761 & .002 \\
\hline & Groups & Linearity & 2522.684 & 1 & 2522.684 & 49.602 & .000 \\
\hline & & Deviation & 1111.524 & 18 & 61.751 & 1.214 & .335 \\
\hline & & from & & & & & \\
\hline & & Linearity & & & & & \\
\hline & Within C & roups & 1017.167 & 20 & 50.858 & & \\
\hline & Total & & 4651.375 & 39 & & & \\
\hline
\end{tabular}

Sumber: Hasil Pengolahan Data, 2018

Hasil pengujian menggunakan uji $\mathrm{F}_{\text {test }}$ didapatkan $\mathrm{F}_{\text {hitung }}$ sebesar 1,214 dengan tingkat signifikansi $0,000 \leq 0,05$ artinya variabel employee engagement $(\mathrm{Y})$ secara keseluruhan model tersebut sudah fit dan terdapat hubungan antara variabel employee engagement terhadap kinerja pegawai sehingga regresi bisa dipakai untuk memprediksi kinerja pegawai.

Langkah selanjutnya setelah melakukan uji linearitas adalah dengan menguji diagram pencar atau diagram serak (scatter plot) yang digunakan untuk mengetahui dan menunjukkan ada tidaknya hubungan antara variabel engagement (y) dan kinerja pegawai (z) melalui penggambaran nilai variabel-variabel tersebut. Hasil pengolahan data tersebut disajikan sebagai berikut.

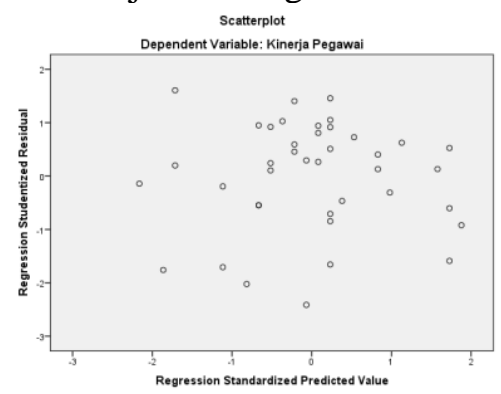

Sumber: Hasil Pengolahan Data, 2018

Gambar 6. Diagram Pencar Kepemimpinan

Employee Engagement Terhadap Kinerja Pegawai

Diagram pencar di atas menggambarkan bahwa titik-titik pada diagram pencar tersebut menyebar dan membentuk pola dari kiri bawah menuju kanan atas. Garis tersebut dapat diketahui kovaransi antara employee engagement (y) dan kinerja pegawai (z) sifatnya searah, dalam arti bahwa apabila employee engagement berubah semakin besar, maka kinerja pegawai pun berubah semakin besar. Setelah diketahui model diagram pencar dan telah menunjukkan pola garis lurus atau linear, langkah selanjutnya adalah memperhatikan titik-titik yang letaknya terpencil pada diagram pencar. Adapun output gambar uji titik terpencil employee engagement terhadap kinerja pegawai dapat dilihat sebagai berikut.

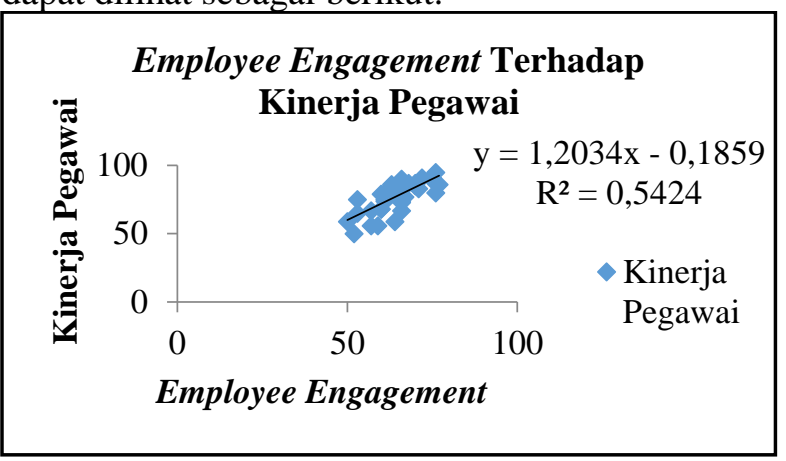

Sumber: Hasil Pengolahan Data, 2018

Gambar 7. Output Uji Titik Terpencil

Employee Engagement Terhadap Kinerja Pegawai

Berdasarkan gambar tersebut, terdapat satu titik hitam yang dicurigai sebagai titik terpencil. Selajutnya untuk mengetahui apakah titik hitam tersebut benar merupakan titik terpencil, maka dilakukan perhitungan dengan menggunakan rumus uji statistik sebagai berikut.

Tabel 9. Hasil Pengujian Titik

Terpencil Employee Engagement Terhadap Kinerja Pegawai

\begin{tabular}{|c|c|c|c|c|c|c|}
\hline$\hat{\mathbf{Y}}$ & $\mathbf{Y}$ & $\mathbf{Z}=\mathbf{a}+\mathbf{b Y}$ & $\begin{array}{c}S_{Y-\hat{Y}} \\
(0,05- \\
\hat{\mathbf{Y}})\end{array}$ & $\begin{array}{c}t_{\text {hitung }} \\
\left.t=\frac{(}{Y-\hat{Y}}\right) \\
s_{Y-\hat{Y}}\end{array}$ & $\begin{array}{c}t_{\text {tabel }} \\
(40- \\
2)\end{array}$ & Keterangan \\
\hline 59 & 64 & $\begin{array}{l}\mathrm{Y}=1,203 \mathrm{x}+ \\
(-0,186) \\
\mathrm{Y}= \\
\quad 1,203(64) \\
\quad+(- \\
\quad 0,186) \\
=76,806\end{array}$ & $\begin{array}{l}0,05- \\
59=- \\
58,95\end{array}$ & $\begin{array}{l}\mathrm{t}=17,806 /- \\
58,95 \\
=-0,302\end{array}$ & 1,686 & $\begin{array}{c}\text { Bukan titik } \\
\text { terpencil }\end{array}$ \\
\hline
\end{tabular}

Sumber: Hasil Pengolahan Data, 2018

Hasil pengujian titik terpencil tersebut, dapat diketahui bahwa titik tersebut bukan titik terpencil, karena $t_{\text {hitung }}$ menunjukkan nilai yang lebih kecil daripada $t_{\text {tabel }}(-0,303<1,686)$. Sehingga, kriteria yang digunakan atas hasil perhitungan tersebut adalah diterima $\mathrm{H}_{0}$ yang 
artinya titik yang mencurigakan tidak dianggap sebagai titik terpencil dan tidak perlu dikeluarkan.

Untuk mengetahui bagaimana pengaruh employee engagement terhadap kinerja pegawai penulis menggunakan analisis regresi linear sederhana guna mengetahui perubahan pengaruh yang terjadi terhadap kedua nilai variabel tersebut. Hasil koefisien regresi dipaparkan sebagai berikut.

\begin{tabular}{|c|c|c|c|c|c|}
\hline \multirow[b]{4}{*}{ Model } & & & & \multirow[b]{4}{*}{$\mathrm{T}$} & \multirow[b]{4}{*}{ Sig. } \\
\hline & \multicolumn{2}{|c|}{$\begin{array}{l}\text { Unstandardized } \\
\text { Coefficients }\end{array}$} & $\begin{array}{l}\text { Standardized } \\
\text { Coefficients }\end{array}$ & & \\
\hline & \multirow[b]{2}{*}{ B } & \multirow{2}{*}{\multicolumn{2}{|c|}{$\begin{array}{l}\text { Std. } \\
\text { Error }\end{array}$}} & & \\
\hline & & & & & \\
\hline 1 (Constant) & -.186 & 11.618 & & -.016 & .987 \\
\hline Employee & 1.203 & .179 & .736 & 6.711 & .000 \\
\hline Engagement & & & & & \\
\hline
\end{tabular}

a. Dependent Variable: Kinerja Pegawai

Sumber: Hasil Pengolahan Data, 2018

Berdasarkan nilai-nilai di atas maka dapat ditentukan model regresi linear sederhana yang dinyatakan dalam bentuk persamaan sebagai berikut.

$$
\begin{gathered}
\mathrm{Z}=\mathbf{a}+\mathbf{b Y} \\
\mathrm{Z}=\mathbf{- 0 , 1 8 6 + 1 , 2 0 3 Y}
\end{gathered}
$$

Nilai konstanta sebesar sebesar $-0,186$ menyatakan bahwa jika tidak ada employee engagement, maka besarnya kinerja pegawai adalah $-0,186$. Koefisien regresi pada variabel employee engagement adalah 1,203 yang memiliki arti bahwa setiap terjadi penambahan nilai pada employee engagement akan terjadi peningkatan kinerja pegawai sebesar 1,203. Sebaliknya, jika terjadi penurunan employee engagement, maka akan menurunkan kinerja pegawai 1,203 satu satuan nilai. Dapat dikatakan bahwa employee engagement yang terjadi dalam organisasi akan berpengaruh terhadap tingkat kinerja pegawai itu sendiri. Jika employee engagement rendah, maka kinerja pegawai akan rendah. Berdasarkan nilai signifikansi dari tabel Coefficients diperoleh nilai sebesar $0,000<0,05$. Sehingga dapat disimpulkan bahwa variabel employee engaement (Y) berpengaruh terhadap variabel kinerja pegawai $(\mathrm{Z})$.

Langkah selanjutnya adalah dengan menganalisis koefisien determinasi yang digunakan untuk mengetahui presentase pengaruh dari variabel employee engagement (y) terhadap variabel kinerja pegawai (z). Sehingga nilai $r$

\begin{tabular}{|c|c|c|c|c|}
\hline \multirow{2}{*}{\multicolumn{5}{|c|}{$\begin{array}{c}\text { Tabel 11. Koefisien Determinasi } \\
\begin{array}{c}\text { Employee Engagement Terhadap Kinerja } \\
\text { Pegawai }\end{array} \\
\text { Model Summary }^{\mathrm{b}}\end{array}$}} \\
\hline & & & & \\
\hline Model & $\mathrm{R}$ & $\begin{array}{c}\mathrm{R} \\
\text { Square }\end{array}$ & $\begin{array}{l}\text { Adjusted R } \\
\text { Square }\end{array}$ & $\begin{array}{l}\text { Std. Error of the } \\
\text { Estimate }\end{array}$ \\
\hline 1 & $.736^{\mathrm{a}}$ & .542 & .530 & 7.485 \\
\hline
\end{tabular}
adalah sebagai berikut.

Sumber: Hasil Pengolahan Data, 2018

Berikut adalah hasil perhitungan koefisien determinasi dari kepemimpinan transformasional (x) terhadap employee engagement (y) dengan menggunakan rumus sebagai berikut.

$$
\begin{aligned}
& \mathrm{KD}=\mathrm{r}^{2} \times 100 \% \\
& \text { (Riduwan, 2013:136) }
\end{aligned}
$$

$\mathrm{KD}=\mathrm{r}^{2} \times 100 \%$

$$
\begin{aligned}
& =(0,736)^{2} \times 100 \% \\
& =0,542 \times 100 \%
\end{aligned}
$$

Hasil perhitungan koefisien determinasi untuk employee engagement (Y) terhadap kinerja pegawai (Z) adalah 54,2\%. Dengan kata lain kinerja pegawai dipengaruhi $54,2 \%$ oleh employee engagement sedangkan 45,8\% dipengaruhi oleh faktor-faktor yang tidak diteliti dalam penelitian ini, misalnya ketidakpuasan karyawan dan motivasi kerja (Talasaz, Saadoldin, \& Shakeri, 2014). Berikut ini rekapitulasi employee engagement terhadap kinerja pegawai.

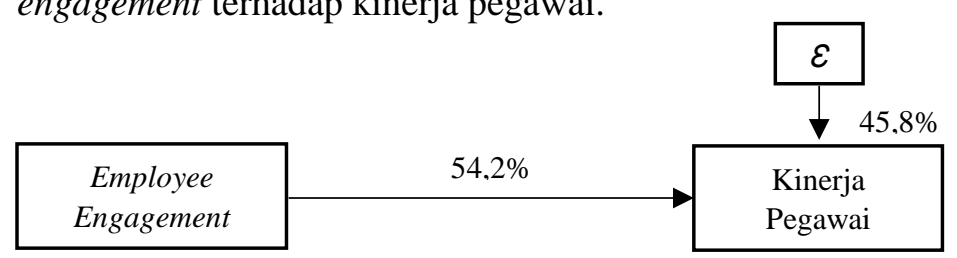

Sumber: Hasil Pengolahan Data, 2018

\section{Gambar 8. Pengaruh Employee Engagement Terhadap Kinerja Pegawai}

Hasil penelitian di atas menunjukkan bahwa terdapat pengaruh antara employee engagement terhadap kinerja pegawai, hal tersebut diperkuat oleh penelitian lain yang menyatakan bahwa employee engagement memiliki pengaruh terhadap kinerja pegawai. Salah satu penelitian dilakukan oleh Anita J dengan cara menyebarkan kuesioner kepada 700 responden yang terdiri dari middle dan lower manajer organisasi skala kecil mengemukakan bahwa employee engagement 
memiliki pengaruh sebesar 59,7\% terhadap kinerja pegawai dan sisanya dipengaruhi oleh variablevariabel yang tidak diteliti oleh penelitian tersebut (Anitha, 2013).

Selanjutnya dilakukan analisis regresi linier sederhana terhadap variabel employee engagement terhadap kinerja pegawai maka langkah selanjutnya dilakukan pengujian hipotesis secara parsial (uji t) terhadap kedua variabel tersebut. Uji statistik t pada dasarnya menunjukkan seberapa jauh pengaruh satu variabel penjelas/independen secara individual dalam menerangkan variabel dependen (Ghozali, 2011:98). Untuk mengetahui besarnya presentase pengaruh employee engagement terhadap kinerja pegawai, maka diperoleh output sebagai berikut.

Tabel 12. Nilai Signifikansi Uji t Employee Engagement Terhadap Kinerja Pegawai

\begin{tabular}{|c|c|c|c|c|c|}
\hline & \multicolumn{3}{|c|}{ Coefficients $^{\mathrm{a}}$} & \multirow[b]{3}{*}{$\mathrm{T}$} & \multirow[b]{3}{*}{ Sig. } \\
\hline \multirow[b]{2}{*}{ Model } & \multicolumn{2}{|c|}{$\begin{array}{l}\text { Unstandardized } \\
\text { Coefficients }\end{array}$} & $\begin{array}{c}\text { Standardized } \\
\text { Coefficients }\end{array}$ & & \\
\hline & B & Std. Error & Beta & & \\
\hline 1 (Constant) & -.186 & 11.618 & & -.016 & .987 \\
\hline Employee & 1.203 & .179 & .736 & 6.711 & .000 \\
\hline Engagement & & & & & \\
\hline
\end{tabular}

Sumber: Hasil Pengolahan Data, 2018

Diketahui nilai $t_{\text {hitung }}$ sebesar $6,711>t_{\text {tabel }}$ sebesar 1,686 dan tingkat signifikansi $(\alpha)$ sebesar $5 \%$ dengan derajat kebebasan $(40-2=38)$, sehingga dapat disimpulkan bahwa $\mathrm{H}_{\mathrm{o}}$ ditolak dan $\mathrm{H}_{\mathrm{a}}$ diterima yang artinya terdapat pengaruh positif antara employee engagement (y) terhadap kinerja pegawai (z) pada organisasi sektor publik.

\section{KESIMPULAN DAN SARAN}

Berdasarkan hasil penelitian yang telah dilakukan mengunakan analisis verifikatif, dapat diambil kesimpulan bahwa employee engagement dipengaruhi oleh kepemimpinan transformasional sebesar 37,1\% sedangkan 63,9\% dipengaruhi oleh faktor-faktor lainnya yang tidak diteliti dalam penelitian ini, seperti lingkungan kerja, hubungan tim dan rekan kerja, pelatihan dan pengembangan karir, kompensasi, kebijakan organisasi, dan kesejahteraan kerja. Hal tersebut mengemukakan bahwa kepemimpinan transformasional berpengaruh secara rendah terhadap employee engagement. Hasil penelitian pun menunjukkan bahwa kinerja pegawai dipengaruhi oleh employee engagement sebesar 54,2\% sedangkan $45,8 \%$ dipengaruhi oleh faktor-faktor yang tidak diteliti dalam penelitian ini seperti ketidakpuasan pegawai dan motivasi kerja. Hal tersebut menjelaskan bahwa employee engagement berpengaruh secara sedang terhadap kinerja pegawai.

Penelitian ini diharapkan dapat membantu peneliti berikutnya dalam melakukan penelitian mengenai kepemimpinan transformasional, employee engagement dan kinerja pegawai dengan menggunakan indikator yang berbeda dari sumber teori yang lebih beragam, dan terhadap objek yang berbeda, karena masih banyaknya keterbatasan dalam penelitian ini, khususnya yang terkait dengan metode penelitian dan teknik pengumpulan data.

\section{DAFTAR PUSTAKA}

Anitha, J. (2013). Determinants of employee engagement and their impact on employee performance. https://doi.org/10.1108/IJPPM-012013-0008

Council, C. L. (2016). Driving Performance and Retention Through Employee Engagement.

Fattah, H. (2017). Kepuasan Kerja dan Kinerja Pegawai. (R. Wardarita, Ed.). Yogyakarta: Elmatera.

Frank, F. D., Finnegan, R. P., \& Taylor, C. R. (2004). "The race for talent: attracting and engaging workers in the twenty-first century." Human Resource Planning, Vol. 27 No, 12-25.

Ghozali, I. (2011). Aplikasi Analisis Multivariate dengan Program IBM SPSS 19. Semarang: Universitas Diponegoro.

Hewitt, A. (2017). 2017 Trends in Global Employee Engagement.

Iqbal, Z. M., Rehan, M., Fatima, A., \& Nawab, S. (2017). The Impact of Organizational Justice on Employee Performance in Public Sector Organization of Pakistan. International Journal of Economics \& Management Sciences, 6(3). https://doi.org/10.4172/2162-6359.1000431

Kaswan. (2015). Sikap Kerja Dari Teori Dan Implementasi Sampai Bukti. (F. Zulhendri, Ed.). Bandung: Alfabeta.

Kiersch, A. H. Z. B. C. (2014). How interpersonal leadership relates to employee engagement.

Macey, W.H., Schneider, B., Barbera, K.M. and Young, S. A. (2011). Employee Engagement: Tools for Analysis, Practice, and Competitive Advantage. (J. W. \& Sons, Ed.). United Kingdom: Wiley Blackwell.

Mann, A., \& Harter, J. (2016). The Worldwide 
Employee Engagement Crisis. Business Journal. Retrieved from http://www.gallup.com/businessjournal/188033/ worldwide-employee-engagement-

crisis.aspx?g_source $=\& g \_$medium $=\& g \_$campaig $\mathrm{n}=$ tiles

Masharyono. (2015). Pengaruh Job Characteristics Terhadap Semangat Kerja Pegawai (Survey Pada Pegawai PNS di Lingkungan Disparbud Jabar). Riset Akuntasi Dan Keuangan, 3(3), 813-830.

Masharyono, \& Senen, S. (2015). Analisis Job Performance Pegawai Honorer Administrasi Dengan Kompetensi Dan Job Characteristic Dalam Mendukung Universitas Pendidikan Indonesia Menjadi Leading And Outstanding ( Job Performance Analysis Temporary Employee Administrative with Competence an. Fokus Ekonomi, 10, 120-137.

Nikbin, M. J. A. J. A. S. S. H. D. (2016). Relationships between work values, communication satisfaction , and employee The case of international joint. https://doi.org/10.1108/MD-01-2015-0003

Obicci, P. . (2015). Effect Of Ethical Leadership On Employee Performance In Uganda. Net Journal Of Business Management, 3(1), 214-220.

Pidesia, Karim, A., \& Irawan, B. (2016). Analisis Kinerja Organisasi Sekertariat Dewan Perwakilan Rakyat Daerah Kabupaten Kutai Barat. Journal Administrative Reform, 4(1).

Riduwan. (2013). Dasar-Dasar Statistika. Bandung: Alfabeta.

Robbins, S. P., \& Judge, T. A. (2015). Perilaku Organisasi - Organizational Behaviour (16th ed.). Salemba Empat.

Sangeeta, S., Avinash, P., \& Anupam, K. (2017). Transformational leadership and turnover: Mediating effects of employee engagement, employer branding, and psychological attachment. Leadership \& Organization Development Journal. https://doi.org/10.1108/LODJ-12-2014-0243

Senen, S. H., Sumiyati, \& Masharyono. (2016). The Effect of Skill Variety, Task Identity, Task Significance, Autonomy and Feedback on Job Performance, 15, 585-588.

Shuck, B., \& Herd, M. . (2012). Employee Engagement and Leadership: Exploring the Convergence of Two Frameworks and Implications for Leadership Development in HRD. Human Resource Development Review. https://doi.org/10.1177/1534484312438211

Talasaz, Z. ., Saadoldin, S. ., \& Shakeri, M. . (2014). The Relationship Between Job Satisfacton And Job Performance Among Midwives Working In Healthcare Centers Of Mashhad, Iran. Journal of Midwifery And Reproductive Health, 2(3), 157-
164.

Welch, M. (2009). The evolution of the employee engagement concept : communication implications. https://doi.org/10.1108/13563281111186968

Widjajanta, B., Senen, S. H., Masharyono, Lisnawati, \& Anggraeni, C. P. (2018). The Impact of Social Media Usage Self-Esteem on Conspicuous Consumption: Instagram User of Hujabers Community Bandung Member. International Journal of EBusiness and EGoverment Studies, 10(2), 1-13.

Youngster.id. (2017). Engagement Tenaga Kerja Milenial Indonesia Hanya 25\%. Retrieved February 2, 2018, from https://youngster.id/featured/engagement-tenagakerja-milenial-indonesia-hanya-25 